\title{
Association of CYP2D6 (G1934A) gene and hematological disturbances in chronic pesticide exposures
}

\author{
Yuttana Sudjaroen ${ }^{1 *}$, Tanunchanok Pitaksilp², Kampol Ruchiwit ${ }^{2}$, Kanittada Thongkao', Pimporn Thongmuang ${ }^{3}$, Kowit \\ Suwannahong ${ }^{4}$ \\ ${ }^{1}$ Department of Applied Science, Faculty of Science and Technology, Suan Sunandha Rajabhat University, Bangkok, Thailand. \\ ${ }^{2}$ Department of Forensic Science, Faculty of Allied Health Sciences, Thammasat University, Pathumthani, Thailand. \\ ${ }^{3}$ College of Allied Health Sciences, Suan Sunandha Rajabhat University, Samut Songkhram, Thailand. \\ ${ }^{4}$ Department of Environmental Health, Faculty of Public Health, Burapha University, Chonburi, Thailand.
}

\section{ARTICLE INFO \\ Received on: $13 / 05 / 2020$ \\ Accepted on: 23/07/2020 \\ Available online: 05/09/2020}

\section{Key words:}

Blood indices, cholinesterase

inhibitors, chronic pesticide

exposure, CYP2D6,

cytochrome P450,

organophosphate.

\begin{abstract}
Cytochrome P450 family genes (CYPs) have common polymorphisms, which are evaluated for pesticide-induced oxidative stress susceptibility. Variant alleles in CYP enzymes may uncover susceptibility biomarkers of environmental toxicity. This study aims to investigate the relationship between CYP2D6 (G1934A) gene polymorphisms and chronic pesticide exposures, and to evaluate the association between CYP2D6 (G1934A) gene polymorphism on biochemical and hematological parameters. A cross-sectional study was carried out at a health promoting hospital, Suphan Buri, Thailand. Rice farmers and a control group ( $n=50$ for each) were recruited and their personal data were collected. Their blood samples were obtained by venepuncture and drawn into plain and Ethylenediaminetetraacetic acid (EDTA) tubes. Serum cholinesterase ( $\mathrm{SChE}$ ), liver function test, kidney function test, and complete blood count were assessed using automatic analyzers; and CYP2D6 (G1934A) genotyping was carried out by polymerase chain reaction-restriction fragment length polymorphism (PCR-RFLP). SChE in rice farmers was significantly lower $(p=0.033)$, which may be related to the use of chlorpyrifos. The genotypes were significantly different between rice farmers and the control group ( $p=0.0001)$, and the GA variant in rice farmers was more frequent. The CYP2D6 (G1934A) (rs 3892097)) gene and SChE level were negatively correlated $(r=-0.258, p=0.009)$. However, other biochemical parameters were not different. Blood indices, including mean corpuscular hemoglobin (MCH), mean corpuscular volume (MCV), and mean corpuscular hemoglobin concentration $(\mathrm{MCHC})$, values of rice farmers were significantly lower than the control group; and $\mathrm{MCH}, \mathrm{MCV}$, and $\mathrm{MCHC}$ values of the GA variant were also significantly lower than the wild type. The GA genotype was associated with hematological toxicity of organophosphate metabolite in chronic exposures.
\end{abstract}

\section{INTRODUCTION}

Pesticides are classified as chemicals which are used to prevent and eliminate weeds or pests. Occupational and environmental exposure can cause adverse health effects and public health risks. Laborers who are exposed to pesticides include farm workers, gardeners, and retailers. People who spray plants with pesticides are frequently exposed at great intensities, which

\section{"Corresponding Author}

Yuttana Sudjaroen, Department of Applied Science, Faculty of Science and Technology, Suan Sunandha Rajabhat University, Bangkok, Thailand. E-mail: yuttana.su@ssru.ac.th are potentially harmful to their health (Kim et al., 2017; Suratman et al., 2015). Developing countries use about $20 \%$ of the world's pesticides. Thailand is the third ranked user of pesticides in AsiaPacific (Tawatsin et al., 2015). The reported cases of the toxic effects of pesticides are predominantly from the central region of Thailand. The number of cases usually increases during the growing season of many crops in the rainy season (May-August) each year, and were found mainly in farmers and farm workers (Sapbamrer, 2018). Central Thailand is an intense rice producer when water conditions allow (Grandstaff and Srisupun, 2014). Agricultural workers in Suphan Buri, Central Thailand, have reported that most of the active insecticide substances in commercial products are abamectin, chlorpyrifos, carbofuran, and cypermethrin 
(Prasertsung, 2012). Chronic pesticide exposure is associated with various adverse health effects, which include metabolic disorder, neurological toxicity, carcinogenicity, oxidative stress, and endocrine and immune disruption (Androutsopoulos et al., 2015; Corsini et al., 2008; Karami-Mohajeri and Abdollahi, 2011). According to a systematic review, acetylcholinesterase (AChE) inhibitor pesticides can affect biochemical metabolism by reducing AChE activity or by affecting organs directly (Karami-Mohajeri and Abdollahi, 2011). However, serum cholinesterase (SChE) is more commonly tested in the laboratory for the indication of organophosphate (OP) and carbamate intoxication. The decrease in SChE defines the exposure rate, including acute and chronic toxicity on exposure of cholinesterase inhibitors (Giacobini, 2004; Sudjaroen and Suwannahong, 2017). Pesticides also possess hematological toxicity, which is associated with aplastic anemia, agranulocytosis, neutropenia, and thrombocytopenia. Both acute and chronic pesticide exposures are related to hematological abnormalities and thalassemia. OP may interact with the iron binding site of hemoglobin, which leads to anemia (Hundekari et al., 2013; Neghab et al., 2018; Steerenberg et al., 2008; Wafa et al., 2013).

Biological effects of pesticide are involved by oxidative stress, epigenetic controls, and gut microbiological digestion; however, genetic polymorphisms are the main occurrences (Karami-Mohajeri and Abdollahi, 2011; Teodoro et al., 2019). The polymorphism of cytochrome $\mathrm{P} 450$ family genes (CYPs) is mainly involved in OP metabolism and is used to evaluate pesticideinduced oxidative stress susceptibility (Kapka-Skrzypczak et al., 2011; Wafa et al., 2013). Variant alleles in CYP enzymes are susceptibility biomarkers of environmental toxicity (Elfaki et al., 2018; Kapka-Skrzypczak et al., 2011). The CYP2D6 (G1934A) (rs 3892097)) gene polymorphism leads to a catalytic rate of enzyme activity (Singh et al. 2011), and CYP2D6 1934A allele is related to the susceptibility of OP chronic toxicity in Egyptians (Tawfik Khattab et al., 2016). This study aims to investigate the relationship between CYP2D6 (G1934A) gene polymorphisms and chronic pesticide exposures by using PCR-RFLP and SChE, respectively, and to evaluate the association between CYP2D6 (G1934A) gene polymorphism, biochemical parameters, including liver function test (LFT) and kidney function test (KFT), and hematological parameters.

\section{SUBJECTS AND METHODS}

\section{Background of research area}

The U-Thong District, Suphan Buri Province, is about $150 \mathrm{~km}$ west of Bangkok. The main harvested product is rice and its varieties, which include Suphan Buri 1 (SPR1), Suphan Buri 2 (SPR2), and Khao Dawk Mali 105. Rice-growing cycles are 2-3 per year due to a low river plain area. The common pesticides used are chlorpyrifos, carbofuran, paraquat, and glyphosate, respectively. Rice field workers are regularly outsourced pesticide sprayers.

\section{Subject recruitment and data collection}

A cross-sectional study was carried out from June 2019 to February 2020, and data were collected annually by the health service program of the health promoting hospital. The study recruited 100 respondents as follows: 50 rice farmers (risk group) aged 18-65 years, who lived in this area, who handled pesticides regularly or worked in paddy fields for 3 years or more; the control group included 50 respondents who lived near the field area and were listed in house registration and had professions not related to farm work. Respondents with a history of serious conditions, such as liver diseases, severe cardiovascular diseases, and cancer, were excluded. Questionnaire interviewing and blood collection were conducted by well-trained research assistants and medical technicians, respectively. The gathered information concerning long-term pesticide exposures, including personal information, adverse health symptoms, personal protective equipment used, and practical knowledge and use of pesticides were recorded by the questionnaires by personal interviewing. The sample size was estimated using the single proportion formula with $95 \%$ confidence interval based on the percentage of abnormal SChE levels in a previous study (Kachaiyaphum et al., 2010). The Ethics Committee of Thammasat University approved this research protocol (COA No. 085/2562). The director of U-Thong district's health promoting hospital, Suphan Buri Province, gave permission to conduct on this study. All participants gave informed consented.

\section{Blood collection, preparation, and storage}

From each participant, $4.5 \mathrm{ml}$ of blood sample was obtained by venepuncture of the median cubital vein in the morning (7-9 a.m.) and was drawn into plain and EDTA tubes of 3 and $1.5 \mathrm{ml}$, respectively. The plain tubes were further centrifuged; and the serum was separated within 2 hours after phlebotomy (Young and Bermes, 1999) for biochemical tests. Whole blood contained in the EDTA tubes were prepared for HbAlc determination and genomic DNA extraction by using the QIAamp blood DNA minikit (QIAGEN Thailand, Bangkok, Thailand). The genomic DNA was stored at $-20^{\circ} \mathrm{C}$.

\section{Evaluation of biochemical and hematological parameters}

The quantitative analysis of SChE, LFT, and KFT was conducted by an automatic analyzer, COBAS c501 (Rochediagnostics, Rotkreuz, Switzerland), which was carried out in certified clinical laboratories. Hematological parameters (complete blood count) were analyzed by Celltac E MEK-7222 (Nihon Kohden, Tomioka, Japan). The interpretation of biochemical and hematological parameters was carried out by comparing the reference value according to the manufacturer's instructions and the Clinical and Laboratory Standards of the Institute.

\section{CYP2D6 (G1934A) polymorphisms by PCR-RFLP}

The DNA template was amplified by polymerase chain reaction (PCR) using forward 5'-GCT TCG CCA ACC ACT CCG-3' and reverse 5'-AAA TCC TGC TCT TCC GAG GC3' primers, which corresponded to CYP2D6 (G1934A) region (Zayed et al., 2015). PCR was carried out in $25 \mu \mathrm{l}$ of total volume, which consisted of $1 \mu \mathrm{l}$ of DNA template, $0.5 \mu \mathrm{l}$ of each primer (20 pmol $/ \mu \mathrm{l}), 5 \mu \mathrm{l}$ of $10 \times$ PCR buffer $\left(1.5 \mathrm{mM} \mathrm{Mg}^{2+}\right)$, including dNTP mixture, and $0.2 \mu \mathrm{l}$ of $1 \mathrm{U}$ AmpliTaq polymerase (Thermo Fisher Scientific, Waltham, MA). PCR was carried out with initial denaturation at $94^{\circ} \mathrm{C}$ for 5 minutes, followed by 35 cycles consisting of denaturation at $94^{\circ} \mathrm{C}$ for 1 minute, annealing at $61^{\circ} \mathrm{C}$ for 1 minute, and extension at $72^{\circ} \mathrm{C}$ for 1 minute, followed by 
final extension at $72^{\circ} \mathrm{C}$ for 7 minutes by using a thermal cycler (Applied Biosystems, Waltham, MA). Restriction fragment length polymorphism was carried out and the DNA product was digested by BstNI Restriction Enzyme (New England Bio Labs, Cambridge, UK). The digested DNA fragments were separated in $2 \%$ of agarose gel electrophoresis apparatus and then stained with ethidium bromide. DNA electropherogram was read by using an ultraviolet transilluminator (Promega, San Luis Obispo, CA). The CYP2D6 (G1934A) single nucleotide polymorphisms were 104 and $230 \mathrm{bp}$ fragments for the 1934G allele and $334 \mathrm{bp}$ fragment (undigested) for the 1934A allele (Tawfik Khattab et al., 2016). The interpretation of CYP2D6 (G1934A) genotypes was represented by 104 and 230 bp fragments for wild type (GG); 104, 230, and $334 \mathrm{bp}$ fragments for heterozygous (GA); and $334 \mathrm{bp}$ fragment for homozygous (AA). Quality test control was carried out by DNA sequencing, which was randomized from $15 \%$ of the samples.

\section{Statistical analysis}

Data distribution was analyzed by the KolmogorovSmirnov test. Descriptive statistic was represented by frequency and mean. Differentiation of personal information and CYP2D6 (G1934A) genotypes between rice farmer and controls groups were analyzed by the chi-squared test. Correlation of SChE and polymorphisms was analyzed by Pearson's correlation. The difference between other biochemical and hematological parameters between two groups and between wild type and variant were analyzed by independent $t$-test. Statistical analysis was carried out by SPSS 21.0 program (SPSS, Chicago, IL) and statistical significance was judged at $p<0.05$.

\section{RESULTS AND DISCUSSION}

\section{Pesticide exposure status in rice farmers}

The rice farmers were mainly men and were older than 40 years. Gender and risk behaviors, such as alcohol consumption, did not show a statistically significant difference between rice farmers and the control group. All the rice farmers had a longterm pesticide exposure and $60 \%$ of them used pesticides for more than 10 years; the rate of pesticide exposure was mainly once or twice per week. The related symptoms of the use of pesticides rarely occurred and almost all of them had knowledge about the awareness of pesticide uses and self-protection. The means of SChE level were significantly different between rice farmers and the control group ( $p=0.033$ ); however, they were within the reference value. In this study, rice farmers were exposed to pesticides for a long time and used pesticides frequently. However, the occurrence of related symptoms was rare, which may be due to nonspecific symptoms that are difficult to define. Unexpected findings may be due to nonspecific symptoms, imprecise explanations in personal interviews, and tolerance of frequently exposed farmers. The majority of rice farmers had been educated about the health awareness and health protection on pesticide use (Table 1).

SChE enzyme has more variation than AChE. However, it was easier to handle during laboratory tests, especially in field work (Nigg and Knaak, 2000). The differences in SChE levels might be due to the different methods used to measure cholinesterase, such as Elman's technique and Michel's change-
Table 1. Personal data and pesticide exposure status of rice farmers.

\begin{tabular}{|c|c|c|c|}
\hline Personal data/exposing factors & $\begin{array}{c}\text { Rice farmer } \\
(\%)\end{array}$ & $\begin{array}{c}\text { Control } \\
(\%)\end{array}$ & $p$-value \\
\hline Gender : Male & $34(68)$ & $30(60)$ & \multirow{2}{*}{0.405} \\
\hline Female & $16(32)$ & $20(40)$ & \\
\hline Age: $<40$ years & $22(44)$ & $40(80)$ & \multirow{2}{*}{$0.0001^{*}$} \\
\hline$\geq 40$ years & $28(56)$ & $10(20)$ & \\
\hline Alcohol intake: none & $36(72)$ & $33(66)$ & \multirow{2}{*}{0.517} \\
\hline Drinking & $14(28)$ & $17(34)$ & \\
\hline Duration of pesticide use: $4-9$ years & $18(36)$ & - & \\
\hline$>10$ years & $32(64)$ & - & \\
\hline Frequency of exposure: $1-2$ days/weeks & $30(60)$ & - & \\
\hline 3-4 days/weeks & $4(8)$ & - & \\
\hline 5-6 days/weeks & $16(32)$ & - & \\
\hline Clinical symptoms: None & $36(72)$ & - & \\
\hline Headache/vertigo & $11(22)$ & - & \\
\hline Abdominal cramp & $3(6)$ & - & \\
\hline Health education: none & $13(26)$ & - & \\
\hline Educated & $37(74)$ & - & \\
\hline Serum cholinesterase $\left(\mathrm{U} / \mathrm{l}^{\mathrm{a}}\right.$ & $7,247.2 \pm 1293.3$ & $7,775.9 \pm 1152.8$ & $0.033^{*}$ \\
\hline
\end{tabular}

a $\mathrm{SChE}$ was screened by paper test before being tested with the automatic analyzer and is represented as mean $\pm \mathrm{SD}$ (reference value $=5,500-13,000 \mathrm{U} / 1$ ).

"Statistically significant at $p<0.05$.

in-pH method (Nigg and Knaak, 2000). Moreover, a variety of laboratory instruments may affect the SChE levels, such as automatic-based or manual-based techniques. Safety behavior and variations in pesticide spraying also affected the SChE level (Shentema et al., 2020). Hence, some studies have reported insignificant or slightly lower SChE levels in chronic exposures (Mathew et al., 2015; Sudjaroen and Suwannahong, 2017). Most of the studies on Thai pesticide exposure had reported exposure of a single type of pesticide; however, a mixture of pesticides is more commonly applied for multicrop cultivation. Thus, the screening of other biomarkers can evaluate chronic pesticide exposure rather than SChE alone, such as pesticide metabolites from blood or urine (Wongta et al., 2018).

\section{CYP2D6 (G1934A) genotype, biochemical, and hematological parameters}

The electrophoresis of DNA fragments of the CYP2D6 (G1934A) gene polymorphism in rice farmers included wild type (GG), heterozygote (GA), and homozygote (AA) (Fig. 1). The genotypic polymorphisms of rice farmers and the control group were significantly different $(p=0.0001)$. Rice farmers had a more frequent GA genotype rather than the control group (Table 2) and AA genotype was not detected in either group. The CYP2D6 (G1934A) gene and SChE level were negatively correlated ( $r=$ $-0.258)$ and were statistically significant $(p=0.009)$ (Table 3$)$. The biochemical parameters were not significantly different between rice farmers and the control group; and they were within the reference values (Table 4). Mean corpuscular volume (MCV), mean corpuscular hemoglobin $(\mathrm{MCH})$, and mean corpuscular hemoglobin concentration $(\mathrm{MCHC})$ values of rice farmers were significantly lower than the control group at $p=0.04,0.045$, and 0.03 , respectively; and $\mathrm{MCHC}$ in rice farmers was lower than the 


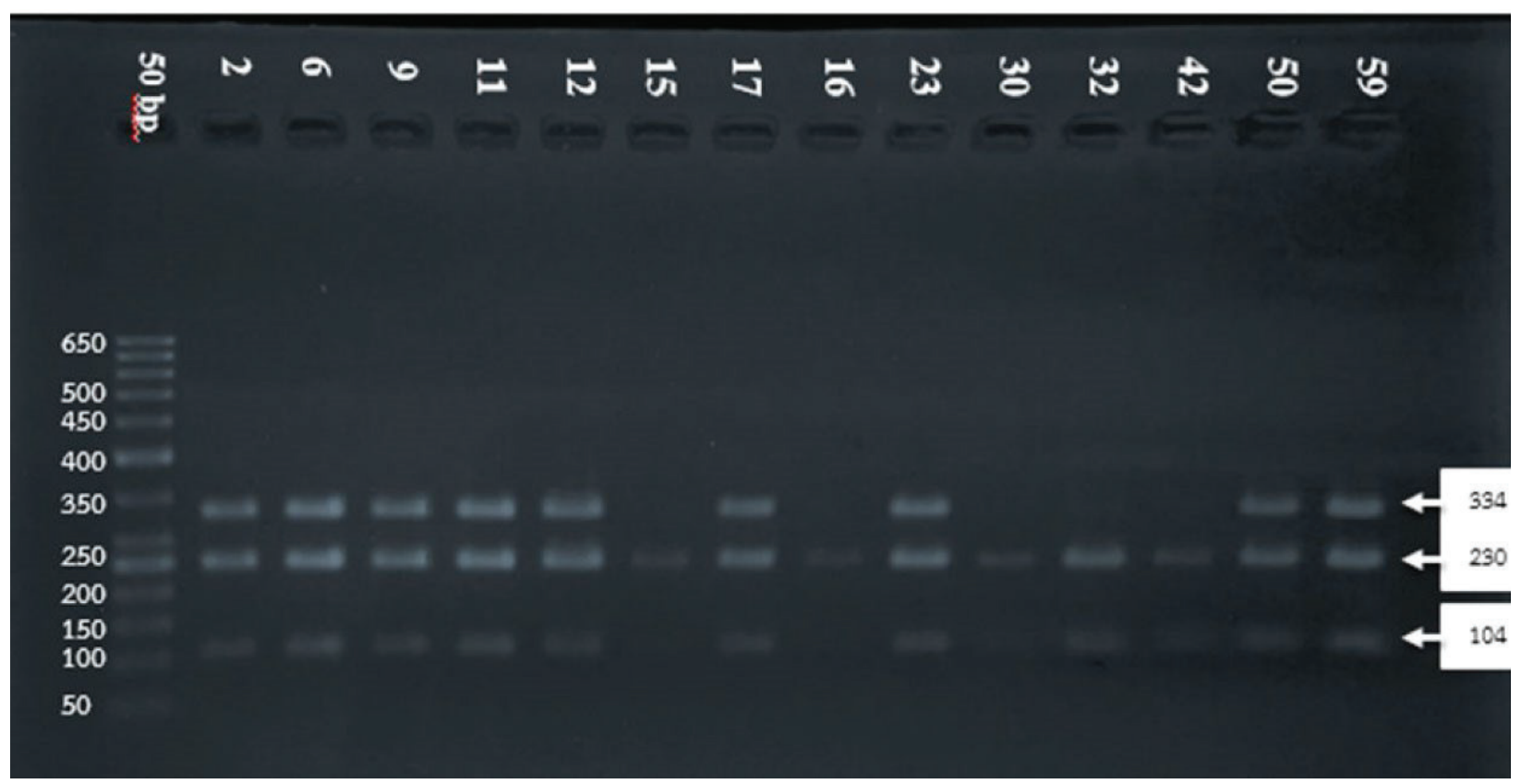

Figure 1. DNA fragment separation. First lane (from left): DNA ladder; lanes 2, 6, 9, 11, 12, 17, 23, 50, and 59: 104 and 230 bp for GA genotype (variant); and lanes 15, 16, 30, 32, and 42: 334 bp for GG genotype (wild type).

Table 2 Genotypic frequency of CYP2D6 (G1934A) in rice farmers and control group

\begin{tabular}{|c|c|c|c|c|c|}
\hline \multirow{2}{*}{ Genotype } & \multicolumn{2}{|c|}{ Control } & \multicolumn{2}{|c|}{ Farmer } & \multirow{2}{*}{$p$-value } \\
\hline & $n$ & $\%$ & $n$ & $\%$ & \\
\hline Wild type (GG genotype) & 44 & 88 & 22 & 44 & \multirow{2}{*}{$0.0001 *$} \\
\hline Polymorphism (GA genotype) ${ }^{\mathrm{a}}$ & 6 & 12 & 28 & 56 & \\
\hline
\end{tabular}

${ }^{a}$ Homozygous polymorphism (AA genotype) was not detected.

"Statistically significant at $p<0.05$.

reference value (Table 5). Moreover, $\mathrm{MCH}, \mathrm{MCV}$, and $\mathrm{MCHC}$ values of GA variant were significantly lower than the wild type at $p=0.029,0.017$, and 0.041, respectively (Table 6).

CYP2D6 is an important member of cytochrome P450 based on various xenobiotic substrates, which shows a very high degree of variability due to the extensive genetic polymorphism that influences gene expression and enzymatic function (Zanger et al., 2004). CYP2D6 gene is involved in the secondary metabolic pathway of desulphuration of isocarbophos (ICP). ICP enantiomers and its oxidative desulphuration metabolite, isocarbophos oxon have been reported to be inhibitors of $\mathrm{AChE}$ (Kaur et al., 2017; Zhuang et al., 2014). The CYP2D6 inhibitors resulted in $50 \%$ inhibition of cholinesterase activity for parathion, $38 \%$ diazinon and $30 \%$ chlorpyrifos as compared to control and $\mathrm{SChE}$ is significantly reduced in chronic OP exposures (Sams et al., 2000; Tawfik Khattab et al., 2016). The variants of CYP2D6 alleles at third intron and four exons resulted in missing of transcription and single based deletion of mRNA (Hanioka et al., 1990). Thus, this finding corresponded to previous study in the reduction of SChE activity and the GA genotype was more susceptible to pesticide than wild type in the Thai population, which was rarely reported. In our study, biochemical parameters in rice farmers were not significantly different; however, lower levels of total protein and albumin in Thai orchid farmers had been report (Aroonvilairat et al., 2015). Other biochemical parameters were also disturbed by chronic pesticide exposure, such as blood glucose and lipid profiles (Patil et al., 2009; Pothu et al., 2019; Ramirez-Vargas et al., 2018). Subclinical change in hematological parameter attracts little attention on pesticide exposure rather than cancer, neurological disorders, epigenetic interaction, oxidative stress, and gene polymorphism (Karami-Mohajeri and Abdollahi, 2011; Neghab et al., 2018; Teodoro et al., 2019). However, hematotoxicity is a biomarker and can indicate occupational exposure along with genotoxicity and oxidative stress occurrence (Ahmadi et al., 2018). In previous studies, abnormal blood indices were found, and the impairment of liver and kidney functions were apparent in pesticide sprayers and agricultural workers (CortésIza et al., 2017; Patil et al., 2009; Sudjaroen and Suwannahong, 2017). Life-long and high-season pesticide use are also associated with lower number of RBC and WBC, particularly lymphocyte and eosinophil (Piccoli et al., 2019). Lower count of B lymphocyte with increments of $\operatorname{IgE}$ level in chronic pesticide exposures was also reported and had implication on immunological disturbance (Aroonvilairat et al., 2015).

CYP2D6 has only a small amount of CYPs $(<2 \%)$, but it metabolizes approximately $25 \%$ of clinically used drugs with significant polymorphisms; it also metabolizes procarcinogens and neurotoxins (Wang et al., 2009). Hence, the variant of CYP2D6 gene was associated with harmful effects of OP metabolite, such as hematological toxicity. Further studies will be conducted on other variants of the CYP2D6 gene, which is associated with the biological effects of other xenobiotics. 
Table 3. Liver and KFT between rice farmers and the control group.

\begin{tabular}{|c|c|c|c|c|c|c|c|c|c|}
\hline \multirow[b]{2}{*}{ Group/parameter } & \multicolumn{7}{|c|}{ LFT } & \multicolumn{2}{|c|}{ KFT } \\
\hline & $\begin{array}{l}\text { Total protein } \\
\text { (g/dl) }\end{array}$ & $\begin{array}{l}\text { Albumin } \\
\text { (g/dl) }\end{array}$ & $\begin{array}{l}\text { Total bilirulin } \\
\text { (mg/dl) }\end{array}$ & $\begin{array}{l}\text { Direct bilirulin } \\
\text { (mg/dl) }\end{array}$ & $\begin{array}{l}\text { AST } \\
\text { (U/I) }\end{array}$ & $\begin{array}{l}\text { ALT } \\
\text { (U/I) }\end{array}$ & $\begin{array}{l}\text { ALP } \\
(\mathbf{U} / \mathbf{l})\end{array}$ & $\begin{array}{c}\text { BUN } \\
\text { (mg/dl) }\end{array}$ & $\begin{array}{c}\text { Creatinine } \\
(\mathrm{mg} / \mathrm{dl})\end{array}$ \\
\hline Rice farmer & $7.29 \pm 0.22$ & $4.50 \pm 0.04$ & $0.36 \pm 0.02$ & $0.13 \pm 0.03$ & $23.0 \pm 1.2$ & $21.7 \pm 2.0$ & $99.9 \pm 3.5$ & $10.8 \pm 4.6$ & $0.85 \pm 0.1$ \\
\hline Control & $7.45 \pm 0.16$ & $4.43 \pm 0.04$ & $0.36 \pm 0.04$ & $0.11 \pm 0.01$ & $23.6 \pm 1.3$ & $24.6 \pm 1.9$ & $101.2 \pm 4.0$ & $9.3 \pm 3.5$ & $0.71 \pm 0.1$ \\
\hline Reference range & $6.60-8.70$ & $3.50-5.50$ & $0.30-1.20$ & $0.00-0.50$ & $0-37.0$ & $0-40.0$ & $53-128$ & $5.0-23.0$ & $0.5-1.52$ \\
\hline$p$-value & 0.552 & 0.282 & 0.964 & 0.485 & 0.744 & 0.308 & 0.797 & 0.561 & 0.152 \\
\hline
\end{tabular}

$\mathrm{AST}=$ aspartate aminotransferase $; \mathrm{ALT}=$ alanine aminotransferase $; \mathrm{ALP}=$ alkaline phosphatase $; \mathrm{BUN}=$ blood urea nitrogen.

Table 4. Hematological parameters in rice farmers and the control group ${ }^{\mathrm{a}}$.

\begin{tabular}{|c|c|c|c|c|c|c|c|c|c|}
\hline Group/parameter & $\operatorname{RBC}\left(10^{6} / \mathrm{mm}^{3}\right)$ & Het(\%) & $\mathrm{Hb}(\mathrm{g} / \mathrm{dl})$ & $\operatorname{MCV}(f l)$ & МCH (pg) & $\operatorname{MCHC}(\mathrm{g} / \mathrm{dl})$ & RDW (\%) & $\mathrm{WBC}\left(10^{3} / \mathrm{mm}^{3}\right)$ & Plt $\left(10^{3} / \mathrm{mm}^{3}\right)$ \\
\hline Rice farmer & $5.16 \pm 0.1$ & $41.8 \pm 0.8$ & $13.5 \pm 0.3$ & $83.4 \pm 1.3$ & $26.0 \pm 0.7$ & $30.3 \pm 0.2$ & $15.3 \pm 0.6$ & $5,895 \pm 265$ & $264,421 \pm 9,627$ \\
\hline Control & $5.13 \pm 0.1$ & $41.8 \pm 1.2$ & $14.5 \pm 0.6$ & $88.4 \pm 1.6$ & $27.8 \pm 0.6$ & $31.7 \pm 0.7$ & $15.0 \pm 0.5$ & $5,699 \pm 241$ & $247,802 \pm 10,424$ \\
\hline Reference range & $4.0-5.5$ & $\begin{array}{c}M=35-49 \\
F=32-42\end{array}$ & $\begin{array}{c}\mathrm{M}=13-18 \\
\mathrm{~F}=12-16\end{array}$ & $80-100$ & $23-33$ & $31-37$ & $12-16$ & $4,000-10,000$ & $140,000-400,000$ \\
\hline$p$-value & 0.84 & 0.984 & 0.154 & 0.045 & 0.04 & 0.03 & 0.757 & 0.587 & 0.244 \\
\hline
\end{tabular}

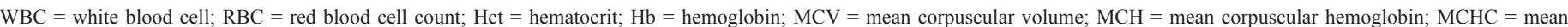
corpuscular hemoglobin concentration; RDW $=\mathrm{RBC}$ distribution width; $\mathrm{Plt}=$ platelet count.

${ }^{a}$ RBC morphology and WBC differentiation with microscopic examination are not shown.

Table 5. Hematological parameters between GG genotype (wild type) and GA genotype (variant).

\begin{tabular}{|c|c|c|c|c|c|c|c|c|c|}
\hline Genotype/parameter & $\operatorname{RBC}\left(10^{6} / \mathrm{mm}^{3}\right)$ & Het(\%) & $\mathrm{Hb}(\mathrm{g} / \mathrm{dl})$ & $\operatorname{MCV}(\mathrm{fl})$ & МCH (pg) & $\operatorname{MCHC}(\mathrm{g} / \mathrm{dl})$ & RDW (\%) & $\mathrm{WBC}\left(10^{3} / \mathbf{m m}^{3}\right)$ & PIt $\left(10^{3} / \mathrm{mm}^{3}\right)$ \\
\hline GG genotype & $5.2 \pm 0.09$ & $42.2 \pm 0.7$ & $14.9 \pm 0.8$ & $89.4 \pm 1.6$ & $28.2 \pm 0.5$ & $31.2 \pm 0.1$ & $15.4 \pm 0.3$ & $5,900 \pm 210$ & $246,756 \pm 10,622$ \\
\hline GA genotype & $5.0 \pm 0.03$ & $41.0 \pm 1.1$ & $13.5 \pm 0.3$ & $84.8 \pm 1.4$ & $26.2 \pm 0.6$ & $29.1 \pm 0.5$ & $14.8 \pm 0.5$ & $5,598 \pm 330$ & $261,133 \pm 9,280$ \\
\hline Reference range & $4.0-5.5$ & $\begin{array}{c}\mathrm{M}=35-49 \\
\mathrm{~F}=32-42\end{array}$ & $\begin{array}{c}M=13-18 \\
F=12-16\end{array}$ & $80-100$ & $23-33$ & $31-37$ & $12-16$ & $4,000-10,000$ & $140,000-400,000$ \\
\hline$p$-value & 0.31 & 0.529 & 0.131 & 0.029 & 0.017 & 0.041 & 0.405 & 0.443 & 0.244 \\
\hline
\end{tabular}

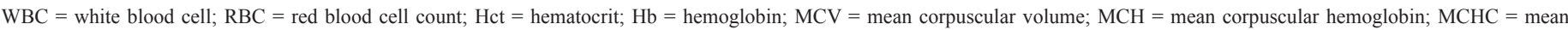
corpuscular hemoglobin concentration; RDW = RBC distribution width; Plt = platelet count.

${ }^{\mathrm{a}} \mathrm{RBC}$ morphology and WBC differentiation with microscopic examination are not shown.

Table 6. Hematological parameters between GG genotype (wild type) and GA genotype (variant)a

\begin{tabular}{|c|c|c|c|c|c|c|c|c|c|}
\hline Genotype/parameter & $\operatorname{RBC}\left(10^{6} / \mathrm{mm}^{3}\right)$ & Het(\%) & $\mathrm{Hb}(\mathrm{g} / \mathrm{dl})$ & $\operatorname{MCV}(\mathrm{fl})$ & MCH (pg) & MCHC(g/dl) & RDW (\%) & $\operatorname{WBC}\left(10^{3} / \mathrm{mm}^{3}\right)$ & PIt $\left(10^{3} / \mathbf{m m}^{3}\right)$ \\
\hline GG genotype & $5.2 \pm 0.09$ & $42.2 \pm 0.7$ & $14.9 \pm 0.8$ & $89.4 \pm 1.6$ & $28.2 \pm 0.5$ & $31.2 \pm 0.1$ & $15.4 \pm 0.3$ & $5,900 \pm 210$ & $246,756 \pm 10,622$ \\
\hline GA genotype & $5.0 \pm 0.03$ & $41.0 \pm 1.1$ & $13.5 \pm 0.3$ & $84.8 \pm 1.4$ & $26.2 \pm 0.6$ & $29.1 \pm 0.5$ & $14.8 \pm 0.5$ & $5,598 \pm 330$ & $261,133 \pm 9,280$ \\
\hline$p$-value & 0.31 & 0.529 & 0.131 & 0.029 & 0.017 & 0.041 & 0.405 & 0.443 & 0.244 \\
\hline
\end{tabular}

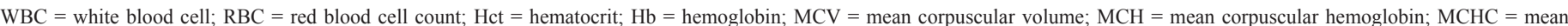
corpuscular hemoglobin concentration; $\mathrm{RDW}=\mathrm{RBC}$ distribution width; $\mathrm{Plt}=$ platelet count .

${ }^{\mathrm{a}} \mathrm{RBC}$ morphology and WBC differentiation with microscopic examination are not shown.

\section{CONCLUSION}

The GA genotype of CYP2D6 (G1934A) gene in chronic pesticide exposures is associated with the alteration of blood indices, including $\mathrm{MCV}, \mathrm{MCH}$, and $\mathrm{MCHC}$.

\section{ACKNOWLEDGMENTS}

We sincerely thank the medical staff from U-Thong district's health promoting hospital, Suphan Buri, Thailand, for the local public relations and the research assistants they provided. We are grateful to Thammasat University, Pathumthani, and Suan
Sunandha Rajabhat University, Bangkok, Thailand, for partial funding support.

\section{CONFLICT OF INTEREST}

There are no conflicts of interest related to this research study.

\section{FUNDING}

None. 


\section{REFERENCES}

Ahmadi N, Mandegary A, Jamshidzadeh A, Mohammadi-Sardoo M, Mohammadi-Sardo M, Salari E, et al. Hematological abnormality, oxidative stress, and genotoxicity induction in the greenhouse pesticide sprayers; investigating the role of NQO1 gene polymorphism. Toxics, 2018; 6:pii: E13.

Androutsopoulos VP, Kanavouras K, Tsatsakis AM. Role of paraoxonase 1 (PON1) in organophosphate metabolism: implications in neurodegenerative diseases. Toxicol Appl Pharmacol, 2011; 256:418-24.

Aroonvilairat S, Kespichayawattana W, Sornprachum T, Chaisuriya P, Siwadune T, Ratanabanangkoon K. Effect of pesticide exposure on immunological, hematological and biochemical parameters in Thai Orchid Farmers - a cross-sectional study. Int J Environ Res Public Health, 2015; 12:5846-61.

Corsini E, Liesivuori J, Vergieva T, Van Loveren H, Colosio C. Effects of pesticide exposure on the human immune system. Hum Exp Toxicol, 2008; 27:671-80.

Cortés-Iza SC, Rodríguez AI, Prieto-Suarez E. Assessment of haematological parameters in workers exposed to organophosphorus pesticides, carbamates and pyrethroids in Cundinamarca 2016-2017. Rev Salud Publica (Bogota), 2017; 19:468-74.

Elfaki I, Mir R, Almutairi FM, Duhier FMA. Cytochrome P450: polymorphisms and roles in cancer, diabetes and atherosclerosis. Asian Pac J Cancer Prev, 2018; 19:2057-70.

Giacobini, E. 2004. Cholinesterase inhibitors: new roles and therapeutic alternatives. Pharmacol Res, 2004; 50:433-40.

Grandstaff S, Srisupun, W. Agropesticide contract sprayers in Central Thailand: health risks and awareness. Southeast Asian Stud, 2004; 42:111-31.

Hanioka N, Kimura S, Meyer UA, Gonzalez FJ. The human CYP2D locus associated with a common genetic defect in drug oxidation: a G1934 A base change in intron 3 of a mutant CYP2D6 allele results in an aberrant 3' splice recognition site. Am J Hum Genet, 1990; 47:994-1001.

Hundekari IA, Suryakar AN, Rathi DB. Acute organophosphorus pesticide poisoning in north Karnataka, India: oxidative damage, haemoglobin level and total leukocyte. Afr Health Sci, 2013; 13:129-36.

Kachaiyaphum P, Howteerakul N, Sujirarat D, Siri S, Suwannapong N. Serum cholinesterase levels of Thai chili-farm workers exposed to chemical pesticides: prevalence estimates and associated factors. J Occup Health, 2010; 52: 89-98.

Kapka-Skrzypczak L, Cyranka M, Skrzypczak M, Kruszewski M. Biomonitoring and biomarkers of organophosphate pesticides exposure - state of the art. Ann Agric Environ Med, 2011; 18:294-303.

Karami-Mohajeri S, Abdollahi M. Toxic influence of organophosphate, carbamate, and organochlorine pesticides on cellular metabolism of lipids, proteins, and carbohydrates: a systematic review. Hum Exp Toxicol, 2011; 30:1119-40.

Kaur G, Jain AK, Singh S. CYP/PON genetic variations as determinant of organophosphate pesticides toxicity. J Genet, 2017; 96(1):187-201.

Kim K-H, Kabir E, Jahan SA. Exposure to pesticides and the associated human health effects. Sci Total Environ, 2017; 575:525-35.

Mathew P, Jose A, Alex RG, Mohan VR. Chronic pesticide exposure: health effects among pesticide sprayers in Southern India. J Occup Environ Med, 2015; 19:95-101.

Neghab M, Jalilian H, Taheri S, Tatar M, Haji Zadeh Z. Evaluation of haematological and biochemical parameters of pesticide retailers following occupational exposure to a mixture of pesticides. Life Sci, 2018; 202:182-7.

Nigg HN, Knaak JB. Blood cholinesterases as human biomarkers of organophosphorus pesticide exposure. Rev Environ Contam Toxicol, 2000; 163:29-111.

Patil JA, Patil AJ, Sontakke AV, Govindwar SP. Occupational pesticides exposure of sprayers of grape gardens in western Maharashtra (India): effects on liver and kidney function. J Basic Clin Physiol Pharmacol, 2009; 20:335-55.
Piccoli C, Cremonese C, Koifman R, Koifman S, Freire C. Occupational exposure to pesticides and haematological alterations: a survey of farm residents in the South of Brazil. Cien Saude Colet, 2019 24:2325-40.

Pothu UK, Thammisetty AK, Nelakuditi LK. Evaluation of cholinesterase and lipid profile levels in chronic pesticide exposed persons. J Family Med Prim Care, 2019; 8:2073-8.

Prasertsung N. Situation of pesticides used in rice fields in Suphanburi Province; proceedings of the conference on chemical pesticides. Available via www.thaipan.org/sites/default/files/conference2555/ conference2555_1_10.pdf(Accessed 15-16 November 2012).

Ramirez-Vargas MA, Flores-Alfaro E, Uriostegui-Acosta M, Alvarez-Fitz P, Parra-Rojas I, Moreno-Godinez ME. Effects of exposure to malathion on blood glucose concentration: a meta-analysis. Environ Sci Pollut Res Int, 2018; 25:3233-42.

Sams C, Mason HJ, Rawbone R. Evidence for the activation of organophosphate pesticides by cytochromes P450 3A4 and 2D6 in human liver microsomes. Toxicol Lett, 2000; 116:217-21.

Sapbamrer R. Pesticide use, poisoning, and knowledge and unsafe occupational practices in Thailand. New Solut, 2018; 28:283-302.

Shentema MG, Kumie A, Bratveit M, Deressa W, Ngowi AV, Moen BE. Pesticide use and serum acetylcholinesterase levels among flower farm workers in Ethiopia - a cross-sectional study. Int J Environ Res Public Health, 2020; 17:964

Singh S, Kumar V, Vashisht K, Singh P, Banerjee BD, Rautela RS, Grover SS, Rawat DS, Pasha ST, Jain SK, Rai A. Role of genetic polymorphisms of CYP1A1, CYP3A5, CYP2C9, CYP2D6, and PON1 in the modulation of DNA damage in workers occupationally exposed to organophosphate pesticides. Toxicol Appl Pharmacol, 2011; 257:84-92.

Steerenberg P, van Amelsvoort L, Colosio C, Corsini E, Fustinoni S, Vergieva T, Zaikov C, Pennanen S, Liesivuori J, Van Loveren $\mathrm{H}$. Toxicological evaluation of the immune function of pesticide workers: a European wide assessment. Hum Exp Toxicol, 2008; 27:701-7.

Sudjaroen Y, Suwannahong K. Comparison of biochemical, hematological parameters and pesticide expose-related symptoms among organic and non-organic farmers, Singburi, Thailand. Asian J Pharm, 2017; 11:S235-41.

Suratman S, Edwards JW, Babina K. Organophosphate pesticides exposure among farmworkers: pathways and risk of adverse health effects. Rev Environ Health, 2015; 30:65-79.

Tawatsin A, Thavara U, Siriyasatien P. Pesticides used in Thailand and toxic effects to human health. Med Res Arch, 2015; 3:1-10.

Tawfik Khattab AM, Zayed AA, Ahmed AI, AbdelAal AG, Mekdad AA. The role of PON1 and CYP2D6 genes in susceptibility to organophosphorus chronic intoxication in Egyptian patients. Neurotoxicology, 2016; 53:102-7.

Teodoro M, Briguglio G, Fenga C, Costa C. Genetic polymorphisms as determinants of pesticide toxicity: recent advances. Toxicol Rep, 2019; 6:564-70.

Wafa T, Nadia K, Amel N, Ikbal C, Insaf T, Asma K, Hedi MA, Mohamed H. Oxidative stress, haematological and biochemical alterations in farmers exposed to pesticides. J Environ Sci Health B, 2013; 48:1058-69.

Wang B, Yang LP, Zhang XZ, Huang SQ, Bartlam M, Zhou SF. New insights into the structural characteristics and functional relevance of the human cytochrome P450 2D6 enzyme. Drug Metab Rev, 2009; 41: 573-643.

Wongta A, Sawarng N, Tongchai P, Sutan K, Kerdnoi T, Prapamontol T, Hongsibsong S. The pesticide exposure of people living in agricultural community, Northern Thailand. J Toxicol, 2018; 2018:7.

Young DS, Bermes EW. Specimen collection and processing: sources of biological variation. In: Burtis CA, Ashwood AR (eds.). Tietz textbook of clinical chemistry. 3rd edition, Saunders, Philadelphia, PA, pp 42-72, 1999.

Zanger UM, Raimundo S, Eichelbaum M. Cytochrome P450 2D6: overview and update on pharmacology, genetics, biochemistry. Naunyn Schmiedebergs Arch Pharmacol, 2004; 369:37-23. 
Zayed AA. AhMed AI Khattab AM, Mekdad AA, AbdelAal AG. Paraoxonase 1 and cytochrome $\mathrm{P} 450$ polymorphisms in susceptibility to acute organophosphorus poisoning in Egyptians. Neurotoxicology, 2015; 51:20-6.

Zhuang XM, Wei X, Tan Y, Xiao WB, Yang HY, Xie JW, Lu $\mathrm{C}, \mathrm{Li} \mathrm{H}$. Contribution of carboxylesterase and cytochrome P450 to the bioactivation and detoxification of isocarbophos and its enantiomers in human liver microsomes. Toxicol Sci, 2014; 140:40-8.
How to cite this article:

Sudjaroen Y, Pitaksilp T, Ruchiwit K, Thongkao K, Thongmuang P, Suwannahong K. Association of CYP2D6 (G1934A) gene and hematological disturbance in chronic pesticide exposures. J Appl Pharm Sci, 2020; 10(09): 065-071. 